\title{
Rural Youth Participation in Major Vegetable Production in Gidda Ayana District, East Wollega Zone, Oromia Rigion, Ethiopia
}

\author{
Waktole Bayisa Debelo, Zelleke Zewudie \\ Salale Agricultural School, Salale University, Salale, Ethiopia \\ Email address: \\ bayw45@gmail.com (W. B. Debelo) \\ To cite this article: \\ Waktole Bayisa Debelo, Zelleke Zewudie. Rural Youth Participation in Major Vegetable Production in Gidda Ayana District, East Wollega \\ Zone, Oromia Rigion, Ethiopia. International Journal of Applied Agricultural Sciences. Vol. 7, No. 4, 2021, pp. $203-212$. \\ doi: $10.11648 /$ j.ijaas.20210704.19
}

Received: July 5, 2021; Accepted: July 19, 2021; Published: August 31, 2021

\begin{abstract}
Agriculture is a vital sector for the achievement of food security, employment creation and economic growth in the world. The climatic and soil conditions of Ethiopia allow cultivation of a wide range of horticultural crop and has a variety of vegetable crops grown in different agro ecological zones produced through commercial as well as small farmers both as a source of income as well as food. Various types of vegetable crops are grown in Ethiopia under rain-fed and irrigation systems. In Ethiopia the total land covered by potato, tomato and cabbage was 160,000 ha; 3,677ha and 38,000ha respectively. The objective of this study was to analyze determinants rural youth participation in major vegetable production in the study area. Three stage sampling procedures were used in this study. The primary data were collected through focus group discussion, key informant interview, interview schedule and observation. Secondary data were collected from review of related literatures and documents. Descriptive statistics, inferential statistics and econometric model such as binary logit regression were used for analyzing quantitative data. The result of binary logit regression model analysis revealed that marital status, education level, farm experience, agricultural input supply, land size, access to irrigation and livestock ownership were statistically significant in affecting youth's to participate in major vegetable production. Therefore, this result implies that improving farmers' level of education, encouraging the agricultural input supply, facilitate opportunity to access more land, improving livestock production system and creating favorable access to irrigation and local government need to encourage youth to participate in major vegetable production.
\end{abstract}

Keywords: Gidda Ayana, Major Vegetable, Participation, Youth

\section{Introduction}

\subsection{Back Ground of the Study}

Ethiopia's national youth policy (2004) specifically defines youth as those aged between 15-29 years. Young people make up the bulk of the labor force (primarily in the agricultural sector) and bear most of the unemployment burden. Each year, more than 10 million African youth enter the continent's workforce, posing a great challenge for youth unemployment and opportunities. For instance, youth unemployment in Ethiopia constitutes $60 \%$ of the total unemployment; and $49 \%$ of working youth live on USD 1.90 a day or less. It has been noted that youth have the time, power, abilities and the capacity to innovate and take risks, although many young people have been underutilized $[8,6]$; International Fund for Agricultural Development. Furthermore, youth participation in rural agriculture is critical in the achievement of Sustainable Development Goal (SDG) number one (1) which deals eradication of extreme poverty and SDG number two that entails to end hunger [20]. However, most of the youth in developing countries like Ethiopia have limited access to the farming resources [11].

Major vegetable production is an important economic activity in Ethiopia, ranging from smallholder farming to large scale commercial farms [22]. While smallholders usually use the largest part of their vegetable produce for home consumption and sell the surplus, the commercial state and private farms produce solely for market. According to [4], about 2,710 million tons of vegetables were produced on 
541,000 ha, creating means of livelihood for more than 1 million households in 2010/2011. The cultivated crop production area increased by $26 \%$, while the production volume increased by $73 \%$ between 2011 and 2013 [5]. Vegetables are also used as a source of raw material for the local processing industry. Processed products such as tomato paste and tomato juice are produced for exports making a significant contribution to the national economy [2]. Increased national and growing regional demand for vegetables has triggered commercial production and boosted private investment in the sector by both national and international entrepreneurs [9].

The agro-ecology of the study area is suitable for vegetable production and other agricultural farming that more people of the area depend on agriculture for their home consumption and source of income. Despite the increasing importance of vegetables in the study area, there is inadequate, farming resource including availability of irrigation, land, improved variety accessibility and income to purchase agricultural technology that enhance youth to participate in major vegetable production in the Gidda Ayana district that was the target area of the present study. The objective of this study was to analyze determinants rural youth participation in major vegetable production in the study area.

\subsection{Statement of the Problem}

The development in cropping system helps for the improvement of standard of living of smallholder farmers who took the major part of the nations of Ethiopia. Despite the fact that major vegetable production and farming technologies such as improved seed and chemical fertilizer is considered as contributing factors for development of the worldwide agriculture and economy of the country. Ethiopia has chronicle poverty and food insecurity problem for a sustained period of time. One of the reasons for the prevalence of food insecurity is low rate of vegetable farming and low use of improved vegetable inputs.
Major vegetables are the most important source of micronutrients and are essential for a balanced and healthy diet. Diversifying and increasing vegetable production can help to overcome malnutrition and poverty by augmenting household consumption and also create new market opportunities for rural and urban youth. As other cereal crops its production in study area was seasonally produced because it depends on rain fed and there is no enough small scale irrigation to produce through the year. There was no adequate organization NGO or government that does on accessibility of irrigation for major vegetable production and considering youth engagement in vegetable farming. In the study area most of youth have not participate in agricultural activity in general and major vegetable production in particular. [13]. The intension of this study was why youths not engage in major vegetable farming and to analyze the impact of participating or not participating in major vegetable production.

Gidda Ayana District produces a wide range of major vegetables including tomatoes, cabbage and potatoes. This major vegetable plays a central role towards meeting food, nutrition security, and source of income and means of economic improvement for the youth in the study area. It is important as a source of employment and increasing foreign currency and it's the most important source of micronutrients and are essential for a balanced and healthy diet in the study area and it is important for food security in times of drought, famine and food shortage.

For instance, extreme weather condition, chicken destruction of vegetable and market problems, lack of technical innovative knowledge in improving production techniques, pest and diseases were factors affect youth in major vegetable farming and they identify these problems by using descriptive statics $[10,12,19,16]$.

Therefore, the aim of this article was to fill the mentioned research gaps on youth participation in major vegetable production taking the case of Gidda Ayana District, East Wollega Zone.

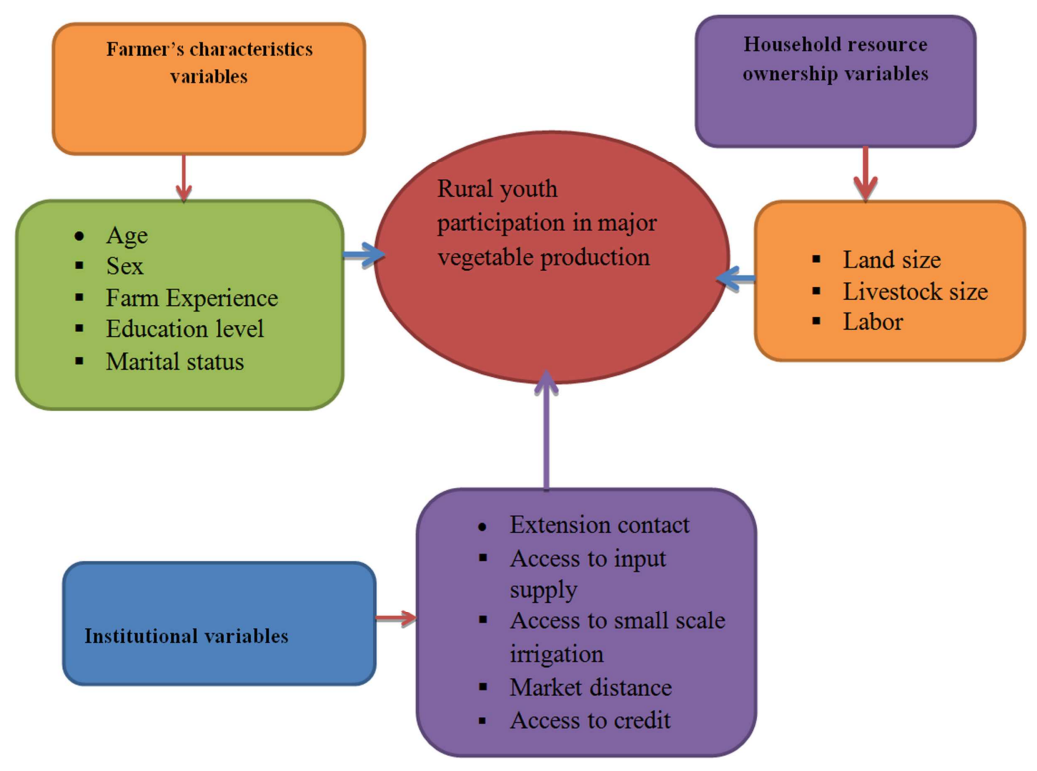

Figure 1. Conceptual Framework. 


\section{Conceptual Framework}

A conceptual framework gives details of the variables that are examined and their expected relationships of the study. It is basically groups the variables into independent, dependent variables. In this study, variables used to depict the background characteristics of respondents, independent variables used to analyze the impact of major vegetable production on rural youth income and to proximate factors that influence rural youth participation in major vegetable production in Gidda Ayana Woreda and the dependent variables was participation decision and outcome variable was youth's income.

\section{Research Methodology}

\subsection{Description of Study Area}

Gidda Ayana is the one of Oromia Regional state Woreda which is located in the east Wollega zone of Oromia. It is 433 $\mathrm{km}$ far from Addis Ababa and $110 \mathrm{~km}$ from Nekemte. Gidda Ayana is bordered on by the south Guto Gidda, on the west by Limu, on the North West by Ebantu, on the North by Benishangul gumuz, on the East by Horo Guduru Wollega zone and kiramu Woreda. Kola agro ecology (lowland) is characterized by relatively hotter and drier climate, whereas Woiyna Dega (middle land) and Dega agro ecology (highland) are wetter and cooler. Using this classification, the study area contains three typical characteristics of climatic zone such as Kola, 48\%, Weyina Dega 50\%, and Dega 2\%, agro-ecological zones. The mean annual temperature and mean annual rainfall of this district was varied between $18 \mathrm{c}$ and $36 \mathrm{c}$ and its mean annual rainfall is $600 \mathrm{~mm}-120 \mathrm{~mm}$. Rainfall of the area is very erratic and scarce occurring two or three times yearly. Survey of the land in these Woreda shows that is arable $65.7 \%$ from the cultivable $61 \%$ under annual crop $22.8 \%$ pasture 8.7 forests and the remaining $2.8 \%$ is considered unusable land and major vegetable potential of the Woreda is about 9063 ha and currently the total land covered by major vegetable were around 7954 ha. Study area have 20 kebeles with 3 administrative towns and total population of $1,25,341$.

Major vegetables play a central role towards meeting food, nutrition security and a source of income for the farmers in general and for youth in particular in the Woreda. The District was participating in a wide range of vegetable farming including tomatoes, onion, cabbage, carrot and potatoes [13]. Major vegetable is one means for economic improvement for the youth in the study area and the most important source of micronutrients and are essential for a balanced and healthy diet. Diversifying and increasing horticultural production can help to overcome malnutrition and poverty by augmenting household consumption and also create new market opportunities for smallholders. Major Vegetable crops are also important for food security in times of drought, famine and food shortage. They provide a source of income for the youth; create employment opportunity and contribution to the national economy as export commodities.

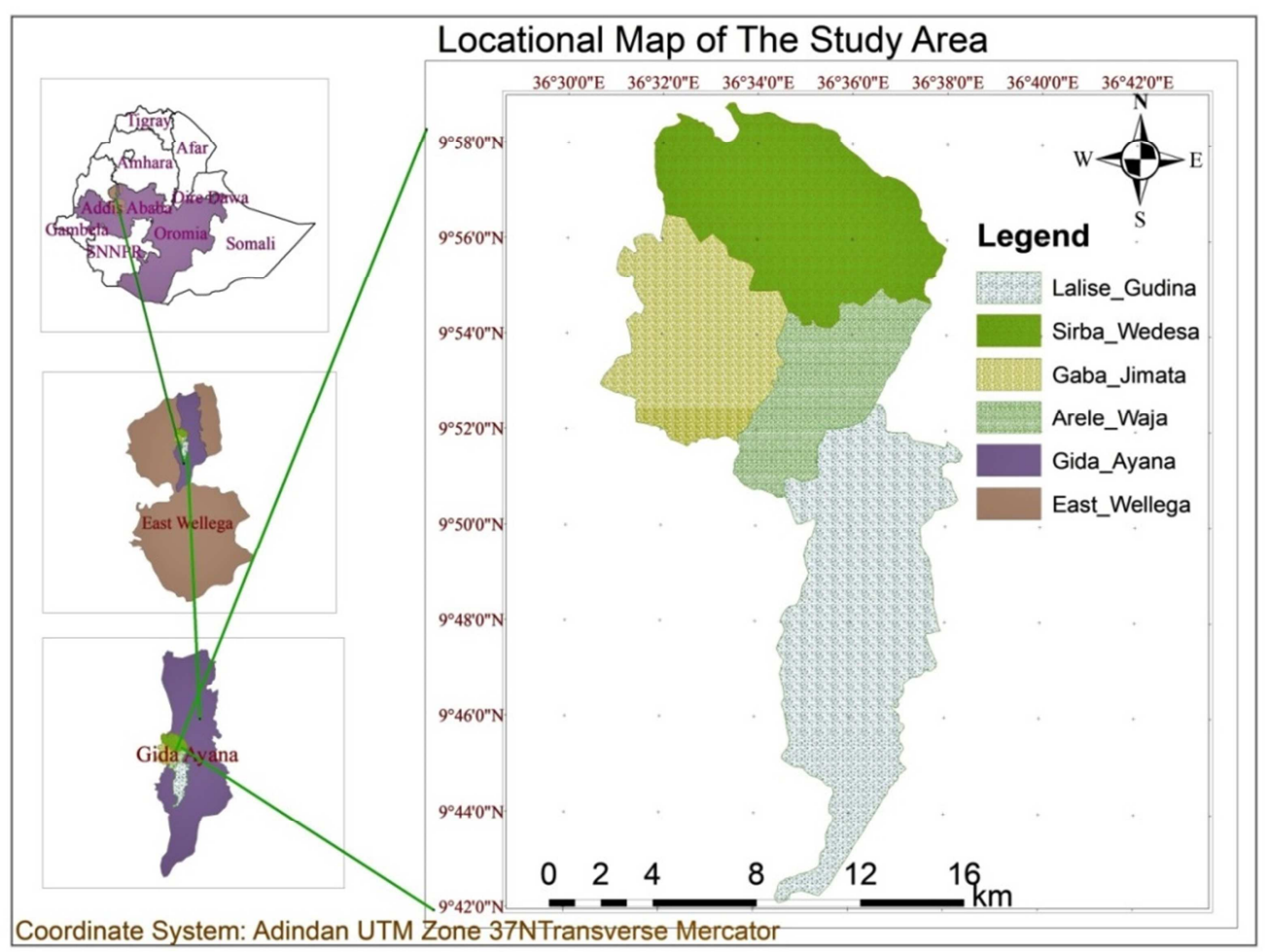

Source: GIS, 2021

Figure 2. Map that describe the study area. 


\subsection{Research Design}

The researcher was used Cross sectional research design. The target population is defined as all rural youth in the Gidda Ayana district of East Wollega zone, Oromia Regional State. This section provides the sample size that was used in the study. In addition, it also gives the sampling procedure that was followed in drawing up the sample to be used in the study. A sampling frame was a complete lists of all the members of the population that researcher studied. The study was used both qualitative and quantitative method. In mixed type, the methods are driven by the research questions linked to the purposes. Identifying the research question and the research purpose (or, because there may be more than just one, the questions and purposes) is to be accomplished through an iterative process.

Quantitatively, youth participation in major vegetable production was measured to identify determinants of youth, participation in the activities. Youth's age, sex, marital status, education, access to credit, access to irrigation, land size, livestock size, farm experience, source of labour, input supply, extension contact, distance from nearest market, was gathered qualitatively, through interview, focus group discussion and observation.

\subsection{Sampling Procedure}

The sample respondents of the study comprised of rural youth farmers including both married and single young men and women. To achieve objective of the study three stage sampling procedure were employed. Accordingly, in the first stage from 20 villages of Gidda Ayana Woreda, a total of four Kebeles were randomly selected to represent the sample. In the second stage because of youth of the study area was heterogeneous or part of them produce major vegetable and the other was not produce; youth was clustered into participant and non-participant in major vegetable production by distributing questionnaires, interviewing youth and searching secondary data from vegetable farming related sector like: - agricultural office and irrigation office. Finally, 85 youth who are participant and 120 non-participant youth in major vegetable production was randomly selected from four villages to represent the sample size of 205 respondents that were used in this study.

\subsection{Sample Size}

The study area has 20 kebeles with 3 administrative towns. From 20 kebeles, a total of four kebeles were selected randomly.

The sample size of this study was determined by using [21].

$$
\mathrm{n}=\frac{N}{1+N(e) 2} \frac{421}{1+421(0.05) 2}=205
$$

$\mathrm{N}=$ Total youth size $\mathrm{n}=$ Selected Sample size by population proportion size

Table 1. Distribution of youth's Sample size (n) in the four settlement areas (pps).

\begin{tabular}{|c|c|c|c|c|c|}
\hline Name of Kebeles & $\begin{array}{l}\text { Non-participant sample } \\
\text { Calculation }\end{array}$ & $\begin{array}{l}\text { Sample of non- } \\
\text { participant }\end{array}$ & $\begin{array}{l}\text { Participant } \\
\text { Sample Calculation }\end{array}$ & $\begin{array}{l}\text { Sample of } \\
\text { participant }\end{array}$ & Total sample size \\
\hline Lalise Guddina & $104 \div 266 \times 120$ & 47 & $25 \div 155 \times 85$ & 14 & 16 female +45 male $=61$ \\
\hline Arele wajja & $72 \div 266 \times 120$ & 32 & $30 \div 155 \times 85$ & 16 & 12 female +36 male $=48$ \\
\hline Sirba Wadessa & $50 \div 266 \times 120$ & 23 & $45 \div 155 \times 85$ & 25 & $14 \mathrm{female}+34 \mathrm{male}=48$ \\
\hline Gaba Jimata & $40 \div 266 \times 110$ & 18 & $55 \div 155 \times 85$ & 30 & 8 female +40 male $=48$ \\
\hline Total & & 120 & & 85 & 205 \\
\hline
\end{tabular}

\subsection{Type and Source of Data}

Both quantitative and qualitative data type were collected from primary and secondary data sources to obtain the necessary information for the purpose of the study. Qualitative data was gathered through key informant interview, focus group discussion and direct observation. Primary data was collected from respondents while, secondary data were reviewed and organized from various documents both published and unpublished materials which are relevant to the study.

The primary data that are supposed to be important for the study were collected from the respondents. Farmer's characteristics variables, household resource ownership variables and institutional related variables relevant to the study such as age of youth, sex of youth, education status of youth, frequency of youth with extension contact, labor availability in youth, distance of youth from nearest market, access to input supply, access to irrigation, farm land size, access to credit and marital status of youth was collected.
Secondary data such as background information of the study area collected from secondary data sources such as from different journal, articles, paper and report of agricultural office of the district.

\subsection{Methods of Data Collection}

Interview schedule was designed and used to collecting quantitative data related to the study. To observe the overall relevance of the instrumentation or questioner and adjust the questionnaire based on the real situation, the questioner was pre-tested before the actual survey carried out. Ten youth respondents which are not included in final data collection were selected and interviewed. Accordingly, some amendment was done on the contents of questioner before actual survey was carried out. Then two development agents were selected for the purpose of data collection that is local language speaker, native to the study area and had experience in data collection technique. Two days training held on the basic interview skills and on the content of the questionnaire. Finally survey carried out in the March 2020. 
To supplement the primary data, focus group discussion held with selected youth farmers to collect qualitative data. Accordingly, two focus group discussions held at each Kebeles having 6-9youth that has 3 females and 6 male members. Checklist was prepared to collect information from FGD with general outline of major vegetable production. The discussions aimed to draw constraints of youth farmers to participate in major vegetable farming.

Key informant interview is other method of qualitative data collection with people who have more knowledge about factors that hinders rural youth participation in vegetable production. The researcher was used key informant interview to collect information from wide range of people including community leaders, elders who have more experience, DAs who have knowledge about existing issues of youth participation in major vegetable production in Gidda Ayana woreda.

Observation: Observation is the qualitative data collection method that researcher was gather information by directly observing what is performing on the ground concerning youth and major vegetable production by directly visiting the performance of participation of youth and on how much farm size they use for major vegetable farming.

\subsection{Methods of Data Analysis}

These study was used both descriptive statistics and econometric model are employed to analyze the data obtained in the survey. Factors that influence youth participation in major vegetable production were analyzed by using binary logit. The quantitative data was analyzed using descriptive and inferential statistical tools. Means, percentages and standard deviation was used to analyze descriptive statistics, while chi-square and t-test were applied to test the statistical significance of the dummy and continuous variables respectively. A t-test was used to examine the mean difference between participant and nonparticipant in major vegetable farming with respect to certain continuous variables. Qualitative data collected from focus group discussion and key informant interview was analyzed by narrative explanation with supported by quantitative data. Finally, the analysis was done with the help of (SPSS ver. 20, STATA version 13.1 and Excel).

Binary logistic Regression Model

The researcher was used this model to analysis the objectives of the study to identify whether youth would have been participated or not participated in major vegetable production. Binary logistic regression model was a proper model when the dependent variable is a dummy one consisting of two, 0 and 1, or more levels; logistic regression model can be properly used. Therefore to identify the major factors affecting youth participation in vegetable production and to identify participant and non-participant ( dummy variable) of youth in vegetable farming, binary logistic regression was used. In order to explain the model, the following logistic distribution function was used.

$$
\mathrm{Pi}=\in(\mathrm{Y}=1 / \mathrm{Xi})=\frac{1}{1+\mathrm{e}^{-(\beta 1+\beta 2 \times i)}}
$$

In the logistic distribution equation, $P i$ is the independent variable; $X \mathbf{1}$ is the data that is the possibility of a preference by an individual (option of having 1 and 0 values). When $\beta$ $1+\beta 2 X i$ in Equation 1 is replaced by $Z i$, Equation 2 is obtained:

$$
\mathrm{Pi}=\frac{1}{1+\mathrm{e}^{-\mathrm{Zi}}}
$$

$Z i$ is between $-\infty$ and $+\infty$, and $P i$ is between 1 and 0 . When $P i$ shows the possibility of participant, the possibility of non-participant of rural youth is $1-P i$. Then, the possibility of non-participant can be explained as in Equation 3 as follows:

$$
1-\mathrm{Pi}=\frac{1}{1+\mathrm{e}^{\mathrm{Zi}}}
$$

Equation 4 is obtained by dividing the participant by nonparticipant:

$$
\frac{\mathrm{Pi}}{1-\mathrm{Pi}}=\frac{1+\mathrm{e}^{\mathrm{Zi}}}{1+\mathrm{e}^{-\mathrm{Zi}}}=e^{Z i}
$$

When the natural logarithm of both sides of the equation is written, Equation 1 is obtained

$$
\mathrm{Li}=\ln \left(\frac{\mathrm{Pi}}{1-\mathrm{Pi}}\right)=\mathrm{Zi}=\beta 1+\beta 2 \mathrm{Xi}
$$

Thus, non-linear logistic regression model is liberalized based on both its parameters and variables. " $L$ " is called "logit" and models such as this called "logit models."In these situations, Equation 1 is used for proper transformations:

$$
\mathrm{Pi}=\in\left(\mathrm{Y}=\frac{1}{\mathrm{Xi}}=\frac{1}{1+\mathrm{e}-(\beta 1+\beta 2 \mathrm{X} 1+\beta 3 \mathrm{X} 2+\cdots+\beta \mathrm{kXk})}\right.
$$

Odds and odds ratio are significant terms in logit model. Odds are defined as the ratio of the number of events that occurred to number of events that did not occur. "Odds ratio" on the other hand, is the ratio of two odds, in other words, the ratio of likelihood to another. In Equation 4, two probabilities, major vegetable participant and non- participant probability of an event are proportioned and this is the odds of proportion. It is important to understand that possibility, odds, and logit concepts, are three different ways of explaining the same thing.

$$
\mathrm{Zi}=\beta \mathrm{o}+\varepsilon \beta \mathrm{iX}+\mathrm{Ui}
$$

Binary logit model is proper model when the dependent variable dummy. it is commonly argued that logit and probit are usually used to established the relationship between house hold characteristics and dichotomies response variables major vegetable producer and non-producer) the advantages of this model is over the linear probability is that the probability bound between zero and one moreover they best fit the nonlinear relationship between the probability of being participant to varies explanatory variables. In principle one can substitute the probit model for logistic model as their formulation are quite comparable the main difference is that the logistic model has slightly flatter tails than the cumulative normal distribution i.e. the probit carve approaches the axes 
more quickly the logistic curve hence binary logistic model is selected for this study.

Table 2. The independent variables and its measurement.

\begin{tabular}{|c|c|c|c|c|}
\hline No & Independent variables $(\mathrm{X})$ & Variable type & Variable definition and measurements & Expected sign \\
\hline 1 & Sex & Dummy & 1 if male, 0 if female & + \\
\hline 2 & Age of farmer & Continuous & Age of Youth measure in years & + \\
\hline 3 & Marital status & Dummy & 1 if married, 0 if unmarried & + \\
\hline 4 & Farming experience & Continuous & Years (how long the youth stay in farming) & + \\
\hline 5 & Education level & Continuous & $\begin{array}{l}\text { level of formal education attain by the youth, measuring by the total number of } \\
\text { years spent in receiving formal education }\end{array}$ & + \\
\hline 6 & Land size & Continuous & Hectare, 1 if large farm size available, whereas 0 for small farm size for youth. & + \\
\hline 7 & Distance from the nearest market & Continuous & $\mathrm{Km}, 1$ if near to market, 0 otherwise. & - \\
\hline 8 & Extension contact & Continuous & Number of extension contact per month. 1 if there is extension contact, 0 if otherwise & + \\
\hline 9 & Access to Credit & Dummy & $\begin{array}{l}1 \text {, if the youth gets credit and } 0 \text {, otherwise. Farmers without cash and no adopt } \\
\text { to credit will find it very difficult to participate in vegetable production }\end{array}$ & + \\
\hline 10 & Access to irrigation & Dummy & 1 if respondent get irrigation services, 0 otherwise & + \\
\hline 11 & Labor availability & Dummy & Measured in man equivalent. If available 1 , whereas not available 0 & + \\
\hline 12 & Access to input supply & Dummy & $1=$ if get input timely $0=$ otherwise & + \\
\hline 13 & Livestock size (TLU) & Continuous & $\begin{array}{l}\text { Measured in (TLU). } 1 \text { if livestock available, whereas } 0 \text { for non-availability of } \\
\text { livestock for youth. }\end{array}$ & + \\
\hline
\end{tabular}

\section{Results and Discussion}

This chapter deals with the analysis of the survey data, status of vegetable production and interpretation of the study results. Such as, demographic and social economic related to sampled household discussed using descriptive statistics and econometric result is the body of this chapter.

Determinants of Rural Youth Participation in Major Vegetable Production in the Study Area.

\subsection{Descriptive Results}

\section{Youth demographic characteristics}

The results of descriptive statistics analysis in table 2 show that, from total sampled youth, $75.6 \%$ of them were found to be male while the rest $24.4 \%$ of them were female. The result of chi2 analysis shows that, there was statistically significant effect of youth participation in major vegetable production at less than 5\% significance level. Of the total sampled respondents $41.7 \%$, of them were participant in major vegetable farming activities while $58.3 \%$ of them have no participation in these activities. It was found that, sex and access to credit have no significant influence on the youth farmers' participation in major vegetable production in the study area. From the result of FGD traditionally female youth have less chance to get land than male youth and not produce their own land; their annual income is lower than male youth.

Marital status was $75 \%$ and $25 \%$ male and female youth respectively for major vegetable producer while $47.5 \%$ and 53.5 for non-producer group where the t-test analysis shows the significant influence of the variable in major vegetable production participation at $1 \%$ significance level. Household's labor availability has positive relationship with participation decision. It was hypothesized that it would affect youth participation in major vegetable farming positively that more productive labor force for agricultural production. It is expected that as the marital status of youth increases, their participation in major vegetable production and production of major vegetable increase as well.
From Table 3 below, it is revealed that the mean age of major vegetable production participant group was 24.05and it was 21.73 for non-participant youth. There was significant mean difference between participant and non- participant youth. The-test of age between participant and nonparticipant was found to be significant $1 \%$ level $(t=5.0)$.

Average educational level of respondents was grade. The mean educational attainment of major vegetable producer and non-producer was found to be 4.11and 2.52grade respectively. There was a significant mean difference between participant and non-participant youth in relation to education level at $1 \%$ significant level $(\mathrm{t}=6.12)$. This indicated that major vegetable producer have more educated than non-producer and the result of key informant interview confirm this idea that youth those have educated are more participate in major vegetable farming than less educated youth to find the way of getting income to change their life.

Land holding of the major vegetable producer and nonproducer youth was 0.66 and 0.39 hectares respectively. This was found to have statistically significant mean difference between the two groups at $1 \%$ significant level $(t=7.2)$. The result shows that participant youth have more land in hectares than non-participant youth in the study area. One of the key informant said that, as you know land is crucial in any agricultural activities. As me I have no enough land to produce this major vegetable, because I know as it is more than other agricultural activity on job creation, income generation and productivity. But due to lack of cultivated land I'm not produce more.

Frequency of extension contact: It was observed in (Table 3 ) bellow that, the average frequency of extension contact among the total respondents was 1.95 times per month. The mean frequency of extension contact for major vegetable producer was 1.04 and for non-producer youth were 0.84 per month respectively. There was no statistically significant difference between participant youth and non-participant youth in terms of frequency of extension contact in the study area $(\mathrm{t}=1.51)$. 
Table 3. Descriptive Result of Dummy variables.

\begin{tabular}{|c|c|c|c|c|c|}
\hline \multirow{2}{*}{ Variables } & & \multirow{2}{*}{$\begin{array}{l}\text { Participant } \\
\text { Percent } \\
\end{array}$} & \multirow{2}{*}{$\begin{array}{l}\text { Non- participant } \\
\text { Percent } \\
\end{array}$} & \multirow{2}{*}{$\begin{array}{l}\text { Total } \\
\text { percent }\end{array}$} & \multirow{2}{*}{$\begin{array}{l}\text { Chi-square } \\
\text { (P-Value) }\end{array}$} \\
\hline & & & & & \\
\hline \multirow{2}{*}{ sex of respondents } & Male & 76.5 & 75 & 75.6 & \multirow{2}{*}{3.876} \\
\hline & Female & 23.5 & 25 & 24.4 & \\
\hline \multirow{2}{*}{ Marital status } & Single & 75.8 & 15.3 & 50.7 & \multirow{2}{*}{$72.96^{* * *}$} \\
\hline & Married & 24.2 & 84.7 & 49.3 & \\
\hline \multirow{2}{*}{ Irrigation } & not access & 85 & 38.8 & 65.9 & \multirow{2}{*}{$47.18 * * *$} \\
\hline & Access & 15 & 61.2 & 34.1 & \\
\hline \multirow[t]{2}{*}{ Credit } & Access & 7.5 & 14.1 & 10.2 & \multirow{2}{*}{2.37} \\
\hline & not access & 92.5 & 85.9 & 89.8 & \\
\hline \multirow[t]{2}{*}{ input access } & Not accessible & 74.2 & 24.7 & 53.7 & \multirow{2}{*}{$48.95 * * *$} \\
\hline & Accessible & 25.8 & 75.3 & 46.3 & \\
\hline \multirow[t]{2}{*}{ Source of labour } & Family labour & 88.3 & 95 & 80 & \multirow{2}{*}{$40.7 * * *$} \\
\hline & Hire labour & 17.7 & 5 & 20 & \\
\hline
\end{tabular}

*** is significant at 1 percent.

Age of Youth: -It is showed that the mean age of youth producer was 24.05 and mean age of non-producer was 21.73 , the mean difference showed that as age increase the probability of youth access to agricultural resource also increase. A youth of 27 age said that when my age was $19 i$ have no any land to engage in farming activity and after my age became 25 years old my father gave me 0.125 ha from his own land as a gift after $i$ was married.

Table 4. Descriptive Result of Continuous variables.

\begin{tabular}{|c|c|c|c|c|c|}
\hline \multirow{2}{*}{ Variables } & \multicolumn{2}{|c|}{ Participant } & \multicolumn{3}{|c|}{ Non Participant } \\
\hline & Mean & Std. Deviation & Mean & Std. Deviation. & T-value \\
\hline Age of Youth & 24.05 & 3.341 & 21.73 & 3.231 & $5.00 * * *$ \\
\hline Education level & 4.11 & 2.366 & 2.52 & 1.335 & $6.12 * * *$ \\
\hline Experience & 3.58 & 1.686 & 2.19 & 1.125 & $7.05 * * *$ \\
\hline Market distance & 6.42 & 2.72 & 6.14 & 2.35 & 0.78 \\
\hline Livestock size. & 2.04 & 0.72 & 1.5 & 0.69 & $5.41 * * *$ \\
\hline Extension contact & 1.04 & 0.91 & .84 & 0.91 & 1.51 \\
\hline
\end{tabular}

*** is significant at 1 percent

\subsection{Econometric Result}

This section presents the result of binary logistic regression. Before running logit model, the existence of multicolinearity among independent variables was tested using contingency coefficient (CC) and Variance Inflation Factor (VIF) between discrete and continuous variables respectively. The result of both tests revealed that, there was no serious multicolinearity problem. As a result, no any variables were dropped from the model.

This study revealed that among thirteen hypothesized variables, seven of them were found to be significant while the rest five variables were not significant in influencing probability of participation in major vegetable production. Based on this; educational level, marital status, access to irrigation, input supply, land size, farm experience and livestock ownership were variables identified by logistic regression model that influence youth probability of participation in major vegetable production.

Marital status: - As the hypothesis marital status was found to be positively and significantly (at $5 \%$ significance level) influencing rural youth participation in major vegetable production in the study area. Accordingly, other factors remain constant the odds ratio showed that as youth become married major vegetable production increase by the factor of
3.09998. This means, youth those getting married have a chance to get access to land and labour force for major vegetable production, because vegetable production is naturally labor intensive. This finding is agree with the married youths have the potentials to participate more in agriculture due to the fact that they have more family responsibilities than unmarried youths. Often, fruit and vegetable production requires twice as much, sometimes up to four times as much labour than the production of cereal crops. Permanent vegetable cultivation requires more labour than the traditional cropping systems with rice followed by seasonal vegetables [14]. As data collected from key informant interview, marital status was influence youth to participate in any agricultural activity including vegetable farming. Married youth is search different way of livelihood to generate income to support and feed his or her family and also way of getting land is concerned with marital status.

During the FGD discussion members of the group express their ideas as "major vegetable production needs more labor than other agricultural activities, because it needs critical land preparation (cultivating more than four rounds and row planting than other.

Education level: -It was found that affect youth's probability of participation in major vegetable production positively and significantly at $1 \%$ significance level. A 
positive relationship between education and vegetable production may highlight that more educated people are more users of agricultural technology than others and the more people are educated the more they are aware of these technologies because they play a great important role in increase of participate in major vegetable production, thereby increasing food security stability and ensure sustainable income generation. In other hand binary regression result odds ratio favor youth participation in major vegetable production increased by factor of 1.38 as youth education level increased by 1 class. This is consistence with the study of highly educated farmers may acquire more easily technical information as their capacity to digest information from various sources is larger than non-educated farmers and This finding is consistent with, educational level of the household head has a positive influence on the speed of technology adoption [1]. The focus group discussion result was support the studies of that youth those have more educated have no interest to engage in vegetable farming rather search nonfarm source of income from urban area of their district.

Access to irrigation: -According to hypothesized in table 2 above access to irrigation is variable that positively and significantly influencing rural youth participation in major vegetable production (at 5\% significance level) in the study area. A positive relationship between the two variables indicate that access to irrigation is very important in that it helps youth to acquire the necessary water in right quantities and qualities for the vegetable producer at the right time. Other factors remain constant odds ratio indicated that as youth get enough access to irrigation, the production of major vegetable production increased by factor of 2.26 .., since vegetables are not drought resistant, water is critical for vegetable production during dry seasons for better quality and higher yields [17]. Key informants argue that irrigation availability is the driver of vegetable farming during dry season and we produce vegetable by using harvesting water. To more participate and produce for market, we need enough access to water and Woreda agricultural office helps us for irrigation facilitation.

Land size: - Cultivated land was hypothesized to influence the participation of youth in major vegetable production positively. Land size owned by farmers had positive and significant effect youth participation in the major vegetable production at $10 \%$ significant level. The odds ratio in favor of youth participation in major vegetable farming increased by a factor of 2.4 as youth land size increase by one hectare. This is due to; land is feasibly the single most important resource, as it is a base for any economic activity especially in rural and agricultural sector. This implies that farm size is an indicator of wealth and a proxy for social status and influence within a community which had positively influenced the use of major vegetable. This result is consistent with the findings whose noted that a large proportion of rural youth's farm on a smaller scale which could be due to shortage of resources for production such as land, finance, labor and noted that Access to land by the youth increases their participation in rural and urban major vegetable production $[15,7]$.

"As you know land is crucial in any agricultural activities. As me I have no enough land to produce this major vegetable, because I know as it is more than other agricultural activity on job creation, income generation and productivity. But due to lack of cultivated land I'm not produce more. Therefore it is good if government find the way how I get land". As information gained from focus group and direct observation small hectares of land was given to vegetable farming and attention that given by youth for major vegetable production and on its' economic importance was very low.

Farm experiences: -It affects youth's probability of participation in major vegetable production positively and statistically significant at $1 \%$ significance level. Furthermore, a positive relationship between participating in major vegetable production and farm experience indicate that youth who have more experience farm may have better skill and knowledge on major vegetable production. In general, the odds ratio of logistic regression model of major vegetable production indicates that favor of probability of participation in major vegetable production by a factor of 1.46 as farm experience increased by 1 year. So based on this idea, as farming experience increases youth ability to accumulate more knowledge and skill on how to produce vegetable. This finding is similar to the study that; increase in the farming experience increases the probability of high level of youth performance in farming and youths participate in agricultural farming over time they acquire enough experience that will enable them to cope with challenges in farming [14].

Access to input: -As hypothesized access to input supply found to be positively and significantly (at 5\% significance level) hindering rural youth participation in major vegetable production in the study area. The odds ratio showed that as other factors remaining constant; if youth get input, major vegetable production increased by factor of 5.47. A positive relationship between major vegetable farming and access to input supply shows that those youth who had access to input supply have relatively more participate in major vegetable production because input supply is the driver of agricultural production and productivity. Furthermore, it was established that youth rarely engaged in procurement of farm inputs mainly due to constraints of farm inputs like seedlings, fertilizers and agrochemicals needed for major vegetable production. This finding is in line with the observation of who noted that youth engaging in vegetable production experienced insufficient income and inadequate farm inputs [3].

Data from key informant interview indicate that input supply was very important for major vegetable production to increase quality and quantity of production but it not access on time for producer and quality of improved seed has its own problem.

Livestock size: -Livestock holding is an important indicator of wealth status for the farm community which is hypothesized to have positive relationship with the participation of youth in major vegetable. Suggesting that the increase in a number of livestock owned increases the 
likelihood off-arm household's choice to engage in vegetable farming. The odds ratio favored participation in major vegetable production increased by factor of 1.64as livestock size increased by one tropical livestock unit (TLU). This implies that youth that have livestock can purchase different agricultural inputs that help them to produce more and generate more income for future investment. Contradict with the Study on pepper marketing showed that livestock showed a negative sign on quantity of vegetable production marketing [18].

Data from focus group discussion also show that; relationship between major vegetable production and livestock size indicate that; in rural economy livestock is a means of income besides their other benefits that helps youth to purchase farm input for agricultural production in general and major vegetable production in particular; because of their religion was not allow them to get credit.

Table 5. Determinants of Youth's participation in major vegetable farming.

\begin{tabular}{llll}
\hline Variables & Odds ratio & Std. Err. & P>z \\
\hline AGE & .046 & .0581111 & 0.415 \\
SEX & .5836035 & .2423557 & 0.195 \\
MARITALSTATUS & $3.099998^{* *}$ & 1.422516 & 0.014 \\
EDUCATIO N & $1.376506^{* * *}$ & .1469124 & 0.003 \\
IRRIGATION & $2.263315^{* *}$ & .8980095 & 0.040 \\
LAND SIZE & $2.431713^{*}$ & 1.670427 & 0.096 \\
FARMEXPE RIANCE & $1.456115^{* * *}$ & .1882188 & 0.004 \\
MARKET DISTANCE & .9990723 & .0773763 & 0.990 \\
CREDIT & .4753984 & .2754225 & 0.199 \\
EXTENCONTACT & .887945 & .1878219 & 0.574 \\
INPUTSUPLY & $5.470119^{* *}$ & 3.717833 & 0.012 \\
LABOR & .8946743 & .4230143 & 0.814 \\
LIVESTOC K SIZE & $1.637902^{*}$ & .4274267 & 0.059 \\
Cons & .0014669 & .0025326 & 0.000 \\
Model diagnosis & & & \\
Number of Obs & 205 & & \\
LR chi2 (13) & 104.50 & & \\
Prob > chi2 & 0.0000 & & \\
Log likelihood & -86.845143 & & \\
Pseudo R2 & 0.3756 & & \\
\hline
\end{tabular}

Note: $* * *, * *, *=$ significance level at $1 \%, 5 \%$ and $10 \%$ respectively Source: own compilation, 2021

\section{Conclusion}

In Ethiopia, major vegetable is becoming a prominent source of income since the crop is the most important cash crop for smallholder farmers in the mid-altitude and highland areas of the country. It has also the big market share in the export market and generating foreign currency for the national economy.

The result shows that marital status has positive and significant influence participation in major vegetable production. This indicates that, the household with more family size will contribute to the higher agricultural production with massive and cheap labor and hence reducing the cost of production than with the families hire in labor. The result further found that land holding size, and Small scale irrigation accessibility of the youth exhibits a hill shaped relationship with the probability of participation in major vegetable production and also land size enables the farm youth to engage in major vegetable farming due to the benefit they derive from major vegetable production participation too.

\section{Lists of Acronyms}

$\begin{array}{ll}\text { UN } & \text { United Nations } \\ \text { USD } & \text { United state Development } \\ \text { CSA } & \text { Central Statistical Agency } \\ \text { MoFED } & \text { Ministry of Finance and Economic Development } \\ \text { UNDP } & \text { United Nation development Program } \\ \text { GDP } & \text { Gross Domestic Product } \\ \text { NLFS } & \text { National Labor Force Surveys } \\ \text { SPSS } & \text { Statistical Package for Social Science package } \\ \text { FDG } & \text { Focus group discussion } \\ \text { SDGs } & \text { Sustainable Development Goals }\end{array}$

\section{References}

[1] Afework Hagos and Lemma Zemedu. (2015). Determinants of improved rice adoption in Fogera district of Ethiopia. Science, Technology and Arts Research Journal, Jan-March 2015, 4 (1) pp. 221-228.

[2] AKLILU, S. (2000): Research achievement on variety development and seed production of vegetable crops in Ethiopia. In: Chadha, M. L., E. C. Altoveros, R. NonoWomdim and H. Mndiga (eds.): AVRDC Africa Regional Program 2000. Varietal evaluation and seed production of vegetable crops. Proceedings of workshop held at AVRDC Africa Regional Program, Arusha, Tanzania from 29 September to 05 October 1997. AVRDC ARP Publication No. 2000-2. Asian Vegetable Research and Development Center - Africa Regional Program, Arusha, Tanzania: 6-11.

[3] Bello, M., Madza, T., \& Saror, S. F. (2011). Nigerian Youth Involvement in Rice Production: A Case Study of Lafia Government Area, Nasarawa State, Nigeria. Journal of Environmental Issues and Agriculture in Developing.

[4] CSA (Central Statistical Authority), (2012). Agricultural sample survey report on area and production of crops (private peasant holdings, Maher season). Volume I. CSA, Ababa, Ethiopia. 128 pp.

[5] CSA, (2013b). Report of the inter censual population survey. Addis Ababa: Central Statistical Agency.

[6] D Silva JL, Samah BA, Shaffril HAM (2012).

[7] Darkey SK, Dzoemku BM, Okorley EL, Gyimah NA, Bluwey FA (2014). Contribution of Urban Vegetable Production to Farmers Livelihood: A case of the Kumasi Metropolis of the Ashanti Region of Ghana. Scientific Papers Series Management, Economic Engineering.

[8] Donye, A. O., Gwary, M. M., Nuhu, H. S., \& Zhintswen, A. A. (2012). Assessment of Youth Involvement in yam production in Wukari Local Government Area of Taraba State, Nigeria. Agriculture and Biology Journal of North America, 3 (8), 311-317, ISSN: 2151-7525, doi: 10.5251/abjna.2012.3.8.311.317. 
[9] EHDA (Ethiopian Horticulture Development Agency) (2011, 2012): Exporting Fruit and Vegetables from Ethiopia: Assessment of development potentials and investment options in the export-oriented fruit and vegetable sector. Addis Ababa, Ethiopia. Downloadable at: http://www.diversityabroad.com/administrator/userpics/useri mage9194.pdf, accessed November 19, 2013: 51.

[10] Ejersa, G. G. (2011). Contributions of vegetable production to the household food security: The Case of Kebeles Surrounding Holeta Town. Master of Science Thesis, Addis Ababa University, Ethiopia.

[11] Filmier, D., \& Fox, L., (2014). Youth employment in SubSaharan Africa. United States of America, Washington DC: Africa Development Series, World Bank, doi: 10.1596/978-14648-0107-5.

[12] Foeken D (2013). The role of urban agriculture in the development of middle-sized towns: Case from East Africa. Journal Geography and Regional Planning 6 (4): 117-131.

[13] Gidda Ayana Agricultural office report (2019). Assessment of current major vegetable production status.

[14] Huong et al. (2013) in the Red River shows that such vegetable cultivation requires more labour than the traditional cropping systems with rice.

[15] Kiguli, L. N., Nuwagaba, A., Mwesigwa, D., Kiguli, J. (2003). Access to land for urban agriculture in Kampala, Uganda. Urban Agriculture Magazine, 11, 11-12.
[16] Nadni and Akwiwu. (2008). Determinants youths' participation in Agriculture in Imo state Nigeria. Journal of Applied Science.

[17] Namwata, B. M. L., Kikula, I. S., \&Kopoka, P. A. (2015). Access of Urban Farmers to Land, Water and Inputs for Urban Agriculture in Dodoma Municipality, Tanzania. Journal of African Studies and Development, 7 (1), 31-40, ISSN: 21412189.

[18] Rehima Mussema, (2007). Analysis of red pepper marketing: The case of Alaba and Siltie in SNNPRS of Ethiopia. M. Scthesis presented to the School of Graduate Studies, Haramaya University. 105p.

[19] Simiyu, R. R. (2012). Gender aspects of Urban Agriculture in Eldoret, Kenya. Leiden, the Netherlands: African Studies Centre.

[20] UNDP, (2016). Sustainable Development Goals. United Nations Development Programme.

[21] Yamane Taro, (1967). Statistics: An Introductory Analysis, (2nd Ed.). Harper and Row: New York.

[22] Zelleke, A. and S. Gebremariam (1991): Role of research for horticultural development in Ethiopia. ISHS Acta Horticulturae 270, International Symposium on Horticultural Economics in Developing Countries, Acta Hort. (ISHS) 270: 189-196. URL http://www.actahort.org/books/270/270_22.htm (referred to 31 March 2015). 